\title{
B-Cell Linker Protein
}

National Cancer Institute

\section{Source}

National Cancer Institute. B-Cell Linker Protein. NCI Thesaurus. Code C26636.

B-cell linker protein (456 aa, $\sim 50 \mathrm{kDa}$ ) is encoded by the human BLNK gene. This protein is involved in co-localizing the B-cell receptor and its downstream signaling targets. 